\title{
SPAIN'S TRANSITION TO DEMOCRACY
}

Dictatorship, Workers and the City. Labour in Greater Barcelona since 1939. By Sebastian Balfour. Oxford: Clarendon Press, 1989. Pp. xii + 288. $£_{30}$.

Making Democracy in Spain: Grass-roots Struggle in the South 1955-1975. By Joe Foweraker. Cambridge: Cambridge University Press, ig89. Pp. xii +289. $£ 25$.

The Spanish Socialist Party. A History of Factionalism. By Richard Gillespie. Oxford: Clarendon Press, 1989. Pp. xxii $+520.4^{\circ}$.

As the years of the Spanish transition recede, the perspective opened up brings its events out of the journalist's domain and closer to the historian's. Yet a curious narrowness of focus remains in some of the current historical analysis of the transition. Implicit is the view that it was a process which involved only the political elite. The shape of the emerging democratic system seems thus determined exclusively by the negotiations conducted between reformist Francoists and high ranking oppositionists in the last year or so of the old regime. An obvious criticism of such a narrow focus is that it completely decontextualizes this political bargaining. The nature of Francoist institutions and the political skill of their inhabitants were important conditioning factors, but they did not constitute the transition per se. This was a much lengthier process in which competing interest groups and strategies were enmeshed. To understand the transition fully we must travel backwards from the 1970 s to investigate the political consequences of Spain's social and economic transformation. It is only by recovering the transition's historical dimension that we will understand the extent of continuity and the limits of change in the crowded years of the 'technical transition' opened up by Franco's death in 1975 .

In different ways and, it must be said, with different degrees of success, both Sebastian Balfour and Joe Foweraker consciously address this need. Their studies are underpinned by an empirically-derived appreciation that the mass action of the labour movement was a vital determinant of political transformation in Spain. As Dr Foweraker's title itself implies, democracy was actively made. The spaces in which a civil society could be reconstructed were created - albeit within a favourable economic context - by collective initiatives. As both authors convincingly argue, either explicitly or implicitly, these spaces were far from being the spontaneous product of the contradiction between economic liberalization and political authoritarianism. Following this line to its logical conclusion would mean sustaining that the transition was entirely predetermined by the structures of Francoism.

In the preface to his study of clandestine labour militancy in southern Spain, Dr Foweraker explains that what awaits the reader is 'a story which is necessarily complex in its construction, but which aims to be simple in its telling'. At various junctures thereafter the author reminds us that he is telling a story. This reiteration is particularly unfortunate in a study where the narrative - often fragmentary and oblique in itself is almost entirely divorced from the author's conceptual analysis. The local study of Jerez is not successfully integrated into the author's more general survey of the political transformation of Francoism at a national level. Indeed, the excessive use of crossreferences in the text draws the reader's attention to the serious inadequacies of structure. In other respects, the problems generated by this study differ for the 
specialist and the general reader. In what is a laudable attempt to restore a historically crucial dimension of Spain's political transformation, by writing the transition from below, the author has fallen between the two proverbial stools. The oral testimony which seems to constitute the bulk of Dr Foweraker's primary material, lends poignant immediacy to his account of southern labour militancy. But it provides few new insights for the specialist reader. At the same time, the fragmentariness of the opening chapters in particular means that the study is inaccessible to the non-specialist. Without a considerable amount of contextual knowledge it is difficult to make sense of the 'biographical fragments' which the author seeks to builds into a 'personal mosaic' intended to represent resistance culture in southern Spain. Later on, as we reach the more general (if at times rather derivative) analysis, Dr Foweraker provides the necessary context. But the infuriating thematic compartmentalization so fragments the argument that the reader either succumbs to confusion or else has to construct his/her own integrated overview. All in all, this is no way for a story-teller to proceed.

In terms of theorizing the transition, neither Foweraker nor Balfour claim that their empirical studies of distinct regions can be used to provide nationally applicable constants. Indeed Sebastian Balfour, in his excellently researched study, stresses the specificity of Barcelona. Yet it is precisely his account which provides us with a stimulating analysis of the transition as a national process.

Dr Balfour has furnished us with a skilful and very readable analysis of the cultural, economic and political evolution of organized labour in Spain's most important industrial concentration. He charts its long march from the subsistence strikes of the r 940 as and 1950 s to the strength and confidence of I960s militancy against a background of greater skills and a booming economy. But in explaining how the official state trade unions were turned around in order to achieve collective bargaining mechanisms and genuine worker representation, Sebastian Balfour also demonstrates how and why democratic reform came to be central to the 1970s' political agenda. In a very real sense democracy in Spain was captured from below. As Foweraker also argues, the sphere of labour action provided a crucial source of democratic values, nurturing expectations of future political practice. The process of collective bargaining changed workers' perceptions beyond the ranks of labour activists and political militants. And democratic change was kept on the agenda by the expectations and activities of a labour movement whose mobilizing capacity would spread by the 1970s to embrace the urban space in a variety of residents' associations and community issues. The scope and depth of this influence established the baseline for the political change negotiated between Franco's political representatives and those of the democratic opposition.

Dr Balfour's study reveals how labour resistance was able to be built up over time in the widening space generated by the contradictions between the regime and capital, and, indeed, between individual regime 'families'. Even in the 1940s, when this space was at its narrowest, following the destruction of organized labour's old institutions in the civil war and the subjugation of a half-starving working class, the solidity of economic action could still on occasions force employers to negotiate with workers' representatives and to cede material improvements. Militancy in these early strikes was sparked by the sheer need to survive. These battles for subsistence, in which women sometimes led, as they would not after, were worlds away from the triumphalist political rhetoric of the clandestine opposition. But it is important to recognize in them the germ of future labour strength. Increasingly, organized workers would be able to exploit the latent conflict of interests between the need of individual employers to have 
their own workers producing and the ideological and pragmatic criteria of the state triumphalist or technocratic - concerned to be seen disciplining the national workforce as a whole. As Foweraker observes, even before economic liberalization and the opening to the market, in the most inauspicious and authoritarian of political environments, collective effort could and did open up some democratic spaces in which the labour force could manoeuvre.

By the I95os working-class action had contributed to the crisis of Franco's semiautarkic economic model. Labour protest put pressure on the government to decree wage increases. But these fuelled inflation which combined with economic stagnation to precipitate a clash in the cabinet. The dispute arose over the direction of economic policy, but its outcome would crucially determine the political future of the Franco regime. Against the old guard interventionists still favouring corporatism and state control were ranged the liberal technocrats who advocated opening Spain up to the market economy, thus allowing wages to find their own level. In this battle the liberals were victorious, courtesy of Franco's personal adjudication. The new liberal economic course, sealed in the cabinet changes of 1957 , was intended to guarantee the regime's political stability. But instead, by initiating a process of social and economic modernization, it only intensified the contradiction between the regime's authoritarian political forms and the dynamic of the new society over which it presided. Most specifically, the regime was increasingly incapable of meeting the needs of either capital or labour. The new labour movement born in the rapid economic expansion of the I960s would play an important part in intensifying these internal contradictions which lay at the heart of the regime's final crisis. It is on this process of turbulent change, gathering pace from 1962 , that Dr Balfour's study concentrates.

In Barcelona the phenomenal urban and industrial growth of the late r95os and I 960 s meant a profound change in the city's own identity. 'Its new profile was the spatial expression of laissez-faire capitalism, corruption and social exploitation'. Urban growth in the towns of the hinterland was particularly uncontrolled. Immigrant labour established unauthorized barrios devoid of even minimal infrastructural benefits - no electricity, transport, or drains. So crude were the conditions endured by the hapless dwellers on this new industrial frontier that the barrios were nicknamed such things as 'Kansas City'. The old traditions of Catalan unionism were broken by this massive immigrant labour influx to Barcelona. By the mid 1960 a mixture of regime repression, biological imperative (by 1965 only $4 \%$ of the region's labour force had experienced the civil war), economic growth and urban expansion had transformed the face of organized labour.

When the state implemented its legislation on collective bargaining in 1962, the intention was to strengthen its political control. But quite the opposite effect resulted. For all that the collective bargaining structure fragmented and compartmentalized the labour force, diminishing its unity, as Sebastian Balfour explains, it still introduced a dynamic which undermined the regime's institutions. The contradictions evident in the new economic approach stemmed from one fundamental problem - the impossibility of modernizing the economy without removing the constraints of political dictatorship. The plant-level bargaining necessary to introduce new technology and work methods requiring the co-operation of the workforce also provided a channel for raising demands for democratic shop-floor representation. The inability of the state union structures to deliver satisfactory agreements led to the creation of unofficial committees which drew up demands and negotiated with management. The whole process of collective bargaining thus strengthened the confidence of workers and enabled them to 
organize autonomously. So it was inside this framework of collective bargaining whose mechanisms had been established by Francoist legislation, that there developed the forms of representative labour organization and protest which would operate thereafter against the regime.

The most important and enduring of these forms in Barcelona and elsewhere were the workers' commissions (CC OO). Dr Balfour's study provides an incisive analysis of the growth of the wide-based CC OO, as the first co-ordinated workers' movement of the post-war period. Born out of ad hoc rank-and-file strike committees in the late 1950s, the workers' commissions' strength depended on their ability to represent rank and file feeling which, in turn, depended on solid and consistent work by labour organizers on the ground. Between 1962 and 1967 the commissions' structure embraced a broad political constituency. Indeed it is well known that both communists (PCE) and catholic activists figured among the most prominent militants. But the CC OO were decapitated as a movement in the period of renewed state repression which accompanied the austerity measures of $1967-9$. The base of the labour movement was distanced from labour opposition activists as communication channels fractured or vanished. In these years of isolation, the CC OO underwent a process of ideological and organizational redefinition, whose outcome was greatly conditioned by the clandestinity in which regime repression forced them to operate. As a result, the new CC OO which emerged to organize amid a resurgence of militancy in 1969 had a structure which was much more closely controlled by the PCE. In this new organizational model, Sebastian Balfour convincingly locates the CGOOs' major underlying weakness in the 1970 s' $^{\prime}$ transitional process.

Under PCE hegemony, the crucial but humdrum daily work of union organization fell victim to party triumphalism. '[T] he leadership of the Communist Party did not actively encourage the development of a union culture in the factories and offices...... the party press was content to see labour protest through the distorting lens of its political vision.' In the 1960 s as in the 1950 , this remained fixed on the notion of a general political strike uniting broad sectors of the population in order to topple the regime. The uni-directional flow of information down the channels of a party operating on a stalinist model meant the realism of this vision was never challenged. Increasingly cut off from factory culture, the PCE had no means of perceiving the inevitably more complex process involved in industrial mobilization around political issues. In particular, as Sebastian Balfour demonstrates for greater Barcelona, the party leadership failed to understand that to mobilize fragmented local labour movements successfully in a mass national political protest, the operation had to be identified in some way with local needs and demands. Instead, all mobilizations of organized labour were assumed to be proof of the correctness of the party's line. Both the PCE and CC OO were weakened because they did not understand the dynamic of the labour mobilization which constituted the basis of their strength. And the reasons for this failure go straight to the heart of the gathering internal crisis which was soon to decimate the PCE.

At another level, of course, one could argue that what mattered in the I97os was the very fact of massive labour mobilization, like that surrounding the Burgos trial of ETA militants in late 1970. Its impact and the constant pressure maintained via innumerable local actions - whatever their precise origins - was a vital influence in the process of political change. Sebastian Balfour's study of Barcelona's labour movement demonstrates to the reader the inappropriateness of viewing the transition as an exercise in management. However unequal the power relations, and whatever the errors of the left, the transition was a dialogue. While the democratic opposition drew its strength 
from the labour movement, the latter's proven capacity to mobilize established the minimum agenda of political change which regime interlocutors were obliged to confront.

When one considers Spain's current political panorama, the great absentee from the history of the clandestine labour and political opposition to Franco is of course the socialist party (PSOE). While it is true that Barcelona has historically eluded the penetrative powers of organized socialism - not least because of the latter's overtly centralist tradition - the fact remains that even outside Catalonia socialists were far more absent than present as an opposition force in the 1950 and 1960s. Sebastian Balfour highlights the problem when he describes how, in the labour sphere, the UGT's isolationism, its refusal to operate inside the official union structure, condemned it to the margins of resistance. As late as 1968 , the UGT's roth exile congress, ignoring the entire CC OO initiative, called, like a voice in the wilderness, for the establishment of democratically elected committees beyond the confines of the Sindicatos Verticales (official state unions). Most telling was the response in 1970 of the Catalan UGT albeit more marginal than most - to the plans for large scale May day actions. 'While large street demonstrations were taking place in Barcelona and its industrial satellites, [they] hired a coach for an excursion to the countryside to avoid the "street disturbances". On their way back, ... the members sang the Internationale, suitably impressing the coach driver.' This memorable anecdote, evoking as it does both passivity and wistful nostalgia, epitomizes the plight of Spanish socialism under the dictatorship. The PSOE was essentially a party of exiles. Its leadership, based in Toulouse, was dominated by intransigent old men for whom the civil war had not ended. This tendency was incarnated in the party's general secretary, Rodolfo Llopis, the faithful lieutenant of Francisco Largo Caballero, the historic I 930 os leader who, in his time, had also wreaked substantial havoc on the organization of the PSOE. Locked in the past, in the familiar time-warp of the exile, Llopis and his supporters fought repeated, no-holds-barred battles to break any attempt by socialist groups in the interior to challenge their isolationist line.

But the exiled leadership was fundamentally incapable of responding to the sweeping social and economic changes which had altered Spain - and the political and labour opposition - beyond recognition. The new situation demanded new strategies and above all new alliances. Given the reality of the anti-Franco opposition inside Spain, this meant some sort of co-operation with the PCE - most immediately in the shape of the CC OO. Socialists in the interior often favoured entryism to the state unions as well as political rapprochement with the communist opposition. But the old guard, who retained an iron grip on the socialist party leadership, were obsessively anti-communist because of their civil war experiences. Their veto condemned organized socialism inside Spain to the sidelines, where it appeared dangerously close to being a historical relic. Growth as a movement would depend on jettisoning Republican nostalgia and elaborating new strategies to meet current needs. The dilemma facing the PSOE by the end of the 6 os was thus to renovate or die. It is the story of this renovation process which forms the core of Richard Gillespie's study of the socialist movement in post-civil war Spain.

This process is most usually perceived in terms of the decisions of three party congresses (1970, 1972 and 1974 ) which confirmed the victory of the renovators (who included a number of prominent veterans) over the históricos. But as Dr Gillespie points out, this was the culmination of a much lengthier, painstaking renewal in the youth and union organizations, hallmarked by the bid to return political control to the organizations of the interior. Above all it was the UGT's renovation, sealed at the 1971 
congress, which prepared the ground for the renovators' break-through in the party the following year. Behind this struggle there lay, of course, the fundamental and growing debate on the PSOE's future in a new Spain. But in the union organization this debate also raised implicitly the question of how much political autonomy the UGT would enjoy - an issue which has been central to recent debate in the Spanish socialist movement.

At the PSOE's congress in August 1972, an obdurate Llopis was removed in his absence from the post of general secretary in circumstances whose byzantine quality recalls Francisco Largo Caballero's own ousting at the hands of fellow socialists in 1937. Henceforward, a majority of the new elected leadership was to be based in Spain. The years up to 1975 continued to be dominated by internal war in the organization. But it was the breakthrough of the Sevillian socialists, who had played a leading role in the drive for renovation, at the PSOE's $13^{\text {th }}$ congress in exile in Suresnes (Paris) in I 974 which would determine the future course of the party. This was the congress which elected both Felipe González and Alfonso Guerra to the national executive of the PSOE. Ironically, in view of the controversial ultra-centralizing reforms for which they would be jointly responsible, in 1974 they were elected on the votes of socialist federations hostile to the centralism of the PSOE's Madrid federation.

Dr Gillespie's is an exhaustively researched book, and a definitive source for the numerous and involved sectional disputes with which the PSOE was riven in the timehonoured tradition of political exiles. The rich vein of detail is often fascinating and sometimes very poignant, as in the description of the dilapidated wooden duplicating device and rather conspicuous Vespa scooter used by a team of PSOE militants to scatter leaflets in working-class districts - until they were caught by Franco's police in August 1960 . These details capture the flavour of resistance culture - the strange mix of everydayness and risk involved in even the most basic level of political activity in which the committed engaged daily with little hope of immediate results. On the other hand, Dr Gillespie's account of the factional disputes is so unremittingly detailed that at times it comes perilously close to swamping even the specialist reader. Moreover, the reader's attempts to connect the PSOE's history to the broader political context of the Franco regime and society in the r 950 os and 60 come up against the vacuum in which considerable sections of Dr Gillespie's analysis are presented. This decontextualization is frustrating, though in a way it also conveys an aspect of the very crisis the book seeks to explain - namely the tunnel vision which afflicted a party of exiles, feeding internal conflict, atrophying action and long depriving the PSOE of a realistic political strategy.

The consolidation of the party leadership by 1975 signalled a new phase in PSOE history. Within the democratic transition, the party would undergo one of its own. But the party's change constituted a more radical break with the past. Under the leadership of Felipe González, the PSOE would move rightwards in a singularly dramatic way. Dr Gillespie's analysis of this phenomenon, while related to the internal logic of the party's renovation - and properly so-provides much more general political context which allows the reader to appreciate the external factors influencing PSOE development both en route to power in the 1970 and as the party of government from 1982. Not the least of these influences was the considerable domestic and foreign pressure on the anti-Franco opposition to accept a consensus model of politics and to seek cross-class compromises accordingly.

This is the direction in which the party leadership sought increasingly to steer. Both Felipe González, the high-profile general secretary and Alfonso Guerra, supremo of the party apparatus and 'fixer' extraordinaire, clearly saw a new electoral model as essential to the PSOE's conquest of power. Accordingly, the role and influence of party congress 
and the membership have been relegated as the leadership sanctions its policies by direct appeal to the power of its electoral mandate. For the PSOE this adjustment has involved both ideological revision and major organizational restructuring. But in a party where ideology has always been a rather superficial affair, it was the reform of party statutes which held the key to Guerra and González' successful imposition of an electoral party model. Dr Gillespie underlines this crucial point. In the watershed year of 1979 it was not the ideological reformulations of party congresses but the amendments to statute which weakened the influence of the rank and file and dissenting groups who opposed political redefinition as the abandonment of socialism. Left-wing socialists expended much energy in the ideological debate over whether or not the party should jettison the description 'marxist'. But the left's efforts were largely misplaced. The real battle for control was waged elsewhere - in the committee which approved the reform of party statute. Once the centralizing reforms had been accepted and 'currents of opinion' outlawed, then the left had lost the war. This effectively meant there was no longer any group inside the party which could resist the González/Guerra electoralist roller-coaster.

In much of this there is a strong throw-back to the past. The historic PSOE died in the rubble of Republican defeat in 1939, though its ghost lived on in exile in the form of Rodolfo Llopis' Toulouse executive. In the battle to salvage a viable socialist project for the new Spain, the PSOE's renovators exorcized that ghost - but not entirely. For they were to perpetuate the party's autocratic tendencies whose extremes derived from the experience of division and eclipse in the r930s. The PSOE of the r 980 os is an ultracentralized party. Indeed opponents on the left and the defeated inside the party would claim it operates pure democratic centralism in which the only function of an internal 'opposition' that cannot effectively oppose policy decisions is to protect the PSOE's cosmetic pluralism.

Such developments in the party have ensured that socialist as well as social opposition to the PSOE government's conservative economic policies would be channelled through the union organization (UGT). The unions - both the UGT and $\mathrm{CC} \mathrm{OO} \mathrm{-} \mathrm{were} \mathrm{the} \mathrm{victims} \mathrm{of} \mathrm{Spain's} \mathrm{transition,} \mathrm{as} \mathrm{Sebastian} \mathrm{Balfour's} \mathrm{study} \mathrm{indicates.}$ Organized labour was marginalized as the transition became focused on the political dialogue between government and opposition parties (in which the PCE was competing with the PSOE). But a decade on, with PSOE policies signifying a frontal assault on workers' living standards, so a ghost from the transition has been conjured in the form of UGT-CC OO rapprochement. To both unions it is now clear that the 'social contract' contained in the October I977 Moncloa agreement has functioned consistently against the interests of their members. Austerity has proved a one-sided affair - purchased at the cost of workers' living standards and often their jobs, while few of the promised social and economic reforms have yet materialized. The most dramatic manifestation to date of this accumulating discontent took the form of the massively supported general strike of ${ }_{14}$ December 1988 .

The PSOE's administration of the crisis and its continuing rightward drift has broken the UGT's 'historic' loyalty, turning the union into one of the party's major critics. In the process this inevitably raises questions about the future of the social democratic model in Spain. There is much empty space on the left, but laying credible claim to it depends on the elaboration of strategies capable of channelling the potential transforming energy of actions like the $1_{4} \mathrm{D}$ as a force for political change. 